\title{
Correlations between traits in soybean (Glycine max L.) naturally infected with Asian rust (Phakopsora pachyrhizi)
}

\author{
B. Rodrigues ${ }^{1}$, F. Serafim², A.P.O. Nogueira', O.T. Hamawaki², L.B. de Sousa ${ }^{2}$ \\ and R.L. Hamawaki ${ }^{3}$ \\ ${ }^{1}$ Instituto de Genética e Bioquímica, Universidade Federal de Uberlândia, \\ Uberlândia, MG, Brasil \\ ${ }^{2}$ Instituto de Ciências Agrárias, Universidade Federal de Uberlândia, Uberlândia, \\ MG, Brasil \\ ${ }^{3}$ Southern Illinois University Carbondale, Urbana, IL, USA \\ Corresponding author: B. Rodrigues \\ E-mail: barbara_2730@msn.com
}

Genet. Mol. Res. 14 (4): 17718-17729 (2015)

Received August 22, 2015

Accepted October 16, 2015

Published December 21, 2015

DOI http://dx.doi.org/10.4238/2015.December.21.45

ABSTRACT. Soybean (Glycine max L.)-breeding programs aim to develop cultivars with high grain yields and high tolerance to Asian soybean rust (Phakopsora pachyrhizi). Considering that the traits targeted for breeding are mainly quantitative in nature, knowledge of associations between traits allows the breeder to formulate indirect selection strategies. In this study, we investigated phenotypic, genotypic, and environmental correlations between the agronomic traits of soybean plants naturally infected with $P$. pachyrhizi, and identified agronomic traits that would be useful in indirectly selecting soybean genotypes for high yields. The study was conducted on the Capim Branco Farm, Uberlândia, Brazil, with 15 soybean genotypes, which were cultivated in a completely randomized block design with four replications. Fourteen phenotypic traits were evaluated using the GENES software. The phenotypic and genotypic correlations were positive and of a high magnitude between the total number of pods and the number of 
pods with two or three grains, indicating that the total number of pods is a useful trait for the indirect selection of soybean genotypes for high grain yields. Strong environmental correlations were found between plant height at blooming and maturity and grain yield and yield components.

Key words: Glycine max; Agronomic trait; Asian rust; Indirect selection

\section{INTRODUCTION}

Soybean (Glycine max L. Merrill) is the most cultivated legume in the world, and is of great economic importance. It is used for the production of animal feed, in natura consumption, biodiesel production, medicinal purposes, etc. (Sediyama et al., 2015). Brazil is the second-largest producer of soybean grains, with an approximate production of 86.1 million tons in the 2013/2014 season that is estimated to be around 90 million tons in 2015, with 30.1 million ha cultivated and an average yield of $2894 \mathrm{~kg} / \mathrm{ha}$ (CONAB, 2015).

Soybeans have been bred to develop cultivars with high grain yields that are adapted to various edaphoclimatic conditions and to resist pathogens (Priolli et al., 2004). Asian soybean rust, a disease whose causal agent is the fungus Phakopsora pachyrhizi, emerged in Brazil in 2001, and is now present in all soybean-producing countries. In Brazil, this pathogen has caused significant losses, which has resulted in increased fungicide use and a reduction in grain yield, with consequently greater production costs and a lower income for the growers (Yorinori and Lazzarotto, 2004). For this reason, soybean breeding programs also aim to develop genotypes that are tolerant to Asian soybean rust.

During the development of new cultivars in a breeding program, regardless of the method adopted, plants that present the best traits in a heterogeneous population are selected, with the goal of selecting genotypes that surpass commercial cultivars in terms of grain yield and agronomic traits. Considering the polygenic nature of the traits targeted in soybean breeding, the adoption of strategies that seek to provide greater selection gains is indispensable (Costa et al., 2004). Knowledge of associations between traits is of great importance in the breeding of any species, if selecting for one of them presents difficulties due to low heritability or measurement problems (Cruz et al., 2012). In this case, indirect selection using another trait that has high heritability and is easily evaluated can be recommended, because the trait will be highly correlated with a trait that is difficult to directly select for (Almeida et al., 2011).

Important soybean cultivar traits are mainly quantitative, are controlled by several smalleffect genes, are greatly influenced by the environment, and it is unknown how many of the traits contribute to the phenotype of the organism, so much so that selection for one trait can trigger a series of changes in other traits (Costa et al., 2004). Information about correlations between traits is of great relevance, as it informs the breeder regarding the changes that occur in a trait when one selects for a correlated trait (Ramalho et al., 2005). Phenotypic, genotypic, and environmental correlations can be estimated, because phenotypic expression is a function of the genotype and/or the environment. Phenotypic correlations are estimated based on directly measured data (Falconer and Mackay, 1996).

The principal cause of genetic correlation is pleiotropism, i.e., the property by which one gene influences two or more traits. Genetic connection is also a cause of genetic correlation; however, it is transitory, and occurs primarily in original populations of divergent crosses (Falconer and Mackay, 1996). The environment becomes a cause of correlation when two traits 
are influenced by the same environmental conditions. Positive estimates indicate that the two traits are benefitted or harmed by the same environmental variations, whereas negative estimates indicate that the environment favors one trait to the detriment of the other (Cruz et al., 2012). Coefficients of correlation are dimensionless, and their absolute values do not exceed the unit, whether positive or negative. Coefficients of correlation equal to zero do not signify the absence of a relationship or dependence, but do signify a lack of a linear relationship between two variables (Nogueira, 2011).

Several studies of correlations between traits have been published in the scientific literature; however, the majority of them have been conducted with agronomic soybean data provided by experiments conducted under normal crop conditions. Therefore, this study investigated the magnitude and direction of phenotypic, genotypic, and environmental correlations when the genotypes studied were naturally infected with the fungus Phakopsora pachyrhizi, which will promote the development of genotypes that have high yields, are environmentally adapted, and are tolerant to Asian rust.

\section{MATERIAL AND METHODS}

\section{Experimental design}

The trial was conducted at the Soybean Breeding Program, Capim Branco Farm (1852'S, $48^{\circ} 20^{\prime} \mathrm{W}$ and $805 \mathrm{~m}$ above mean sea level), Federal University of Uberlândia, Uberlândia, MG, Brazil, in December 2013. The treatments consisted of 15 soybean genotypes: nine lines developed by the Soybean Breeding Program (UFUS L110, UFUS L15, UFUS L24, UFUS 26, UFUS 27, UFUS 36, UFUS L139, UFUS 54, and UFUS 69) and six cultivars (UFUS Capim Branco, UFUS Riqueza, UFUS Vila Rica, MSOY 6101, BRS GO 7560, and TMG 801, the last two were tolerant of Asian rust).

A completely randomized block design with four replications was used. The plots were composed of four 5-m long rows of soybean plants with $0.50 \mathrm{~m}$ between each row; the useable area was the two center rows, and $0.50 \mathrm{~m}$ of each extremity was not included. The experiment was conducted using a conventional sowing system in dystrophic dark red latosol, which had been under soybean cultivation for several years. An aeration, two gradations, and plowing were performed prior to sowing, and the plots were fertilized with formula NPK 02-20-10. Sowing was performed manually, at a density of 12 plants per linear meter. The seeds were treated at sowing with a directed jet of fungicide and insecticide, as well as inoculated with the bacteria Bradyrhizobium japonicum using the liquid inoculant, Masterfix.

For weed control, pre-emergent applications $(2.0 \mathrm{~L} / \mathrm{ha})$ of the herbicide DUAL GOLD ${ }^{\circledR}$ (S-metolachlor) were conducted, and post-emergent applications (for weeds with three pairs of leaves) of Cobra ${ }^{\circledR}$ (lactofen) $(0.4 \mathrm{~L} / \mathrm{ha})$ and Classic $^{\circledR}$ (Chromium-ethyl) $(40 \mathrm{~g} / \mathrm{ha}$ ) were performed in order to control weeds with wide and narrow leaves, respectively.

\section{Traits evaluated}

The stages of soybean development were identified according to Fehr and Caviness (1977). All of the evaluations were conducted on five plants that were randomly sampled from each plot; the following traits were sampled: 
a) Number of days to bloom (NDB); the period that corresponds to the number of days elapsed between emergence and blooming (stage R1).

b) Number of days to maturity (NDM); the period that corresponds to the number of days elapsed from emergence to the date that $95 \%$ of the pods mature (stage R8).

c) Height of the plant at bloom (HPB); measured in centimeters from the surface of the soil to the last node on the main stalk in stage R1.

d) Height of the plant at maturity (HPM); measured in centimeters from the surface of the soil to the last node of the main stalk in stage R8.

e) Height of the insertion of the 1st pod (HIFP); measured in centimeters from the surface of the soil to the insertion of the first pod on the main stalk.

f) Number of nodes on the main stalk in bloom (NNB); direct counting of all of the visible nodes on the main stalk in stage R1.

g) Number of nodes on the main stalk at maturity (NNM); direct counting of all of the visible nodes on the main stalk in stage R8.

h) Number of grains per pod; after harvesting, the total number of pods on each plant was counted. They were then ranked as NP1G (number of pods with one grain), NP2G (number of pods with two grains), or NP3G (number of pods with three grains), and subsequently the TNP (total number of pods) per plant was calculated.

i) Severity of Asian rust (SEV, \%); evaluations were conducted on five central trefoil leaflets per plot from the appearance of the first blisters until total defoliation, the average severity being an estimate of the disease average in the plot. The diagrammatic scale shown below (Figure 1) was adopted from Godoy et al. (2006).

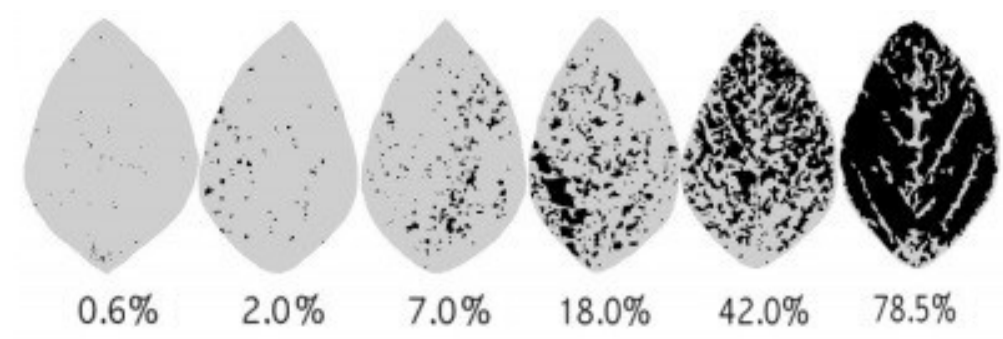

Figure 1. Diagrammatic scale to evaluate the severity of Asian rust.

j) Number of blisters (NB); the number of blisters $/ \mathrm{cm}^{-2}$ on the central leaflet of the middle third of the plant in a $1-\mathrm{cm}^{2}$ area on the right side and center of the leaf was counted with a magnifying glass.

k) Yield (Y); evaluated after harvesting and processing of the plants from the useable area of each plot. The grains were then weighed. The data obtained (grams per plot) were transformed into $\mathrm{kg} / \mathrm{ha}$, this being the yield corrected for $13 \%$ moisture, according to the following equation:

$$
\mathrm{FW}=\mathrm{IW} \times \frac{100-\mathrm{IM}}{100-\mathrm{FM}}
$$

(Equation 1)

where FW is the final corrected weight of the sample, IW is the initial weight of the sample, IM is the initial moisture of the sample, and FM is the final moisture of the sample (13\%). 


\section{Statistical analyses}

After tabulating the data, individual variance analyses were performed using the following model:

$$
Y_{i j}=\mu+B_{j}+G_{i}+E_{i j}
$$

(Equation 2)

where $Y_{i j}$ is the phenotypic value of the trait of genotype $i$ in block $j, \mu$ is the overall average, $B_{j}$ is the random effect of block $j, G_{i}$ is the fixed effect of genotype $I$, and $E_{i j}$ is the random error. From the variance analysis, the coefficient of genotypic determination was estimated as:

$$
H^{2}=\frac{\hat{\phi}_{g}}{\frac{M S T}{r}}
$$

and

$$
\hat{\phi}_{g}=\frac{M S T-M S R}{r}
$$

where $Y_{i j}$ is the quadratic genetic component, $H^{2}$ is the coefficient of genotypic determination, MST is the mean square of treatments (genotypes), MSR is the mean square of the residual, and $r$ is the number of replications. The phenotypic, genotypic, and environmental correlations were performed according to the estimates below.

\section{Phenotypic correlations}

$$
\mathrm{rp}=\frac{\text { APGxy }}{\sqrt{\text { MSGx MSGy }}}
$$

where $r p$ is the estimator of the phenotypic correlation, $A P G_{x y}$ is the average product between the genotypes for the traits $X$ and $Y, M S G_{x}$ is the mean square between the genotypes for the trait $X$, and $\mathrm{MSG}_{\mathrm{y}}$ is the mean square between the genotypes for the trait $\mathrm{Y}$.

\section{Genotypic correlations}

$$
\begin{aligned}
& \mathrm{rg}=\frac{\text { APGxy }- \text { SPRxy } / \mathrm{r}}{\sqrt{\widehat{\phi}_{g}(X) \widehat{\phi}_{g}(Y)}} \\
& \widehat{\emptyset}_{\mathrm{g}(\mathrm{X})=\frac{\mathrm{MSG}_{\mathrm{X}}-\mathrm{MSR}_{\mathrm{X}}}{\mathrm{r}}} \\
& \widehat{\emptyset}_{\mathrm{g}(\mathrm{Y})=\frac{\mathrm{MSG}_{\mathrm{Y}}-\mathrm{MSR}_{\mathrm{Y}}}{\mathrm{r}}}
\end{aligned}
$$

where $\mathrm{rg}$ is the estimator of the genotypic correlation, $\mathrm{SPR}_{\mathrm{xy}}$ is the square of the product between 
the residuals for the traits $\mathrm{X}$ and $\mathrm{Y}, \widehat{\emptyset}_{\mathrm{g}}(\mathrm{XY})$ is the estimator of the genotypic covariance, $\widehat{\emptyset}_{\mathrm{g}}(\mathrm{X})$ and $\widehat{\emptyset}_{\mathrm{g}}(\mathrm{Y})$ are the estimators of the quadratic components associated with the genotypic variability for the traits $\mathrm{X}$ and $\mathrm{Y}$, respectively.

\section{Environmental correlations}

$$
\mathrm{re}=\frac{\text { SPRxy }}{\sqrt{\text { MSRx MSRy }}}
$$

where re is the estimator of the environmental correlation, $\mathrm{SPR}_{\mathrm{xy}}$ is the square of the product between the residuals for the traits $\mathrm{X}$ and $\mathrm{Y}, \mathrm{MSR}_{\mathrm{x}}$ is the mean square between the residuals for trait $\mathrm{X}$, and $\mathrm{MSR}_{\mathrm{y}}$ is the mean square between the residuals for the trait $\mathrm{Y}$. The significance of the phenotypic correlation was estimated using the Student $t$-test, with $(\mathrm{N}-2)$ degrees of freedom, where $\mathrm{n}$ corresponds to the number of genotypes evaluated. The significance of the genotypic and environmental correlations was evaluated by bootstrapping with 5000 simulations. All of the statistical analyses were performed using the GENES software (Cruz, 2008).

\section{RESULTS AND DISCUSSION}

Genetic variability was detected in most of the traits studied to a $1 \%$ probability level by the F test, with the exception of HIFP, NP1G, and NB (Table 1).

Table 1. Summary of a variance analysis of agronomic traits in 15 soybean genotypes naturally infected with Phakopsora pachyrhizi.

\begin{tabular}{|c|c|c|c|c|c|}
\hline Trait & QMG & CV (\%) & $H^{2}$ & CVg (\%) & $\mathrm{CV}_{\mathrm{g}} / \mathrm{CV}_{\mathrm{e}}$ \\
\hline HPB & $104.58^{\star *}$ & 8.61 & 88.16 & 11.75 & 1.36 \\
\hline HPM & $202.84^{\star *}$ & 8.22 & 91.10 & 13.15 & 1.60 \\
\hline NNB & $1.87^{\star *}$ & 5.74 & 80.35 & 5.81 & 1.01 \\
\hline NNM & $23.77^{\star *}$ & 6.34 & 96.30 & 18.18 & 2.55 \\
\hline NDB & $155.63^{\star *}$ & 3.70 & 97.44 & 11.44 & 3.08 \\
\hline NDM & $562.34^{* *}$ & 2.74 & 98.00 & 9.67 & 3.52 \\
\hline HIFP & $32.99^{\text {ns }}$ & 36.27 & 36.57 & 13.77 & 0.38 \\
\hline NP1G & $4.33^{\mathrm{ns}}$ & 74.79 & 45.58 & 34.23 & 0.46 \\
\hline NP2G & $1223.01^{* *}$ & 45.83 & 85.33 & 55.28 & 1.21 \\
\hline NP3G & $641.24^{\star *}$ & 32.10 & 89.62 & 47.16 & 1.47 \\
\hline TNP & $3176.42^{* *}$ & 33.77 & 88.46 & 46.75 & 1.38 \\
\hline Y & $4729200.00^{* *}$ & 27.02 & 86.64 & 34.43 & 1.27 \\
\hline SEV & $0.54^{\star \star}$ & 15.00 & 77.93 & 14.14 & 0.94 \\
\hline NB & $2.02^{\mathrm{ns}}$ & 44.44 & 37.70 & 17.31 & 0.39 \\
\hline
\end{tabular}

**Significant at the $1 \%$ probability level. ns, not significant; QMG, mean square of the genotypes; CV, coefficient of variation; $H^{2}$, coefficient of genotypic correlation; $\mathrm{CVg}$, coefficient of genetic variance; $\mathrm{CVg} / \mathrm{CVe}$, ratio of the coefficient of genetic variance to that of environmental variance; HPB and HPM, height of the plant in bloom and at maturity, respectively; NNB and NNM, number of nodes on the main stalk and at maturity, respectively; NDB and NDM, number of days to bloom and number of days to maturity, respectively; HIFP, height of the insertion of the first pod; NP1G, number of pods with one grain; NP2G, number of pods with two grains; NP3G, number of pods with three grains; TNP, total number of pods; Y, grain yield; SEV, severity of Asian rust; NB, number of blisters $/ \mathrm{cm}^{2}$.

Polizel et al. (2013) also reported the absence of genetic variability for NP1G and NB when evaluating the agronomic performance of 28 early- and mid-cycle soybean genotypes. However, Glasenapp et al. (2015) reported genetic variability in HIFP and NP1G when evaluating agronomic traits in 17 soybean genotypes under greenhouse conditions, with and without Asian 
rust inoculation. The coefficient of variation (CV) obtained from the variance analysis is indicative of the degree of precision of the experiment. In a breeding program, CV ranking can be used, for example, to assess the experimental quality of intermediate and final trials of this crop, where one set of traits is measured to aid the breeder in the description and indication of new cultivars (Carvalho et al., 2003). The lower the CV, the greater the homogeneity, and, consequently, the lower the random variation (Lima et al., 2004). The CV estimates fluctuated between 2.74 and $74.79 \%$ for NDM and NP1G, respectively (Table 1 ). The CVs obtained in this study were acceptable for trials conducted in the field.

The CV values obtained for HPB and HPM (Table 1) agree with those obtained by Gomez et al. (2014) and are within the limit suggested by Carvalho et al. (2003), which indicates a maximum value of $12 \%$ for plant height. However, the same authors suggest $16 \%$ for $Y$ in soybean, which was not observed in this study. However, it is important to emphasize that CV values greater than $20 \%$ have also been obtained by other researchers. Bárbaro et al. (2007) reported CVs that varied between 21.41 and $47.34 \%$ when evaluating $Y$ in generations F4 and F5 of seven soybean populations for two consecutive years. The low CV values we obtained for NDB and NDM (Table 1) corroborate those obtained by Alves et al. (2013) and Gomez et al. (2014).

The CVs for HIFP, NP1G, NP2G, NP3G, and TNP were greater than 30\% (Table 1). These results agree with those obtained by Glasenapp et al. (2015) for HIFP, NP1G, NP2G, and NP3G, which had CVs of $34.20,80.79,39.19$, and $56.29 \%$, respectively. Estimates reported by Okonwo and Idahosa (2013) with five soybean genotypes have obtained CV of $50.46 \%$ for NTV and $31.47 \%$ for grain yield $(Y)$ when evaluating heritability and correlations between traits of soybean in Nigeria. Nogueira et al. (2012) reported a CV of $29.19 \%$ for HIFP and $16.74 \%$ for $Y$ when evaluating 90 soybean genotypes.

$\mathrm{H}^{2}$ is a genetic parameter of fundamental importance in breeding, as it directly influences the selection gains. When the treatments are considered as fixed effects, $H^{2}$ is designated the coefficient of genotypic determination (Vasconcelos et al., 2012). $H^{2}$ estimates varied between $36.57 \%$ for HIFP to $98.00 \%$ for NDM (Table 1). According to Matsuo et al. (2011), high $H^{2}$ values indicate the predominance of genetic effects and low environmental influence on trait expression. The $H^{2}$ values for HPB, HPM, NNB, NNM, NDB, and NDM were all high, as all were greater than $70 \%$ (Table 1). Similar results for NDB, NDM, and HPM were obtained by Bahr et al. (2014) with 48 soybean genotypes, and Malek et al. (2014) who obtained $H^{2}$ values greater than $77 \%$ with 31 soybean genotypes. The low $\mathrm{H}^{2}$ estimates for HIFP (Table 1 ) resemble the values obtained by Cargnelutti Filho and Gonçalves (2001), who obtained estimates of between 0.02 and 0.31 with 28 soybean genotypes in five experiments. Y, as well as its components (NP2G, NP3G, and TNP), had high $H^{2}$ values, with the exception of NP1G (Table 1). Bahr et al. (2014) reported similar values for TNP and Y.

The coefficients of genetic variation $\left(\mathrm{CV}_{\mathrm{g}}\right)$ varied from 5.81 to $55.28 \%$ for NNB and NP2G, respectively (Table 1). In general, values for the ratio of the $\mathrm{CV}_{\mathrm{g}}$ to the coefficient of experimental variation were higher than 1 (Table 1). High CVg and $\mathrm{H}^{2}$ values indicate favorable conditions for phenotypic selection and genetic gain (Malek et al., 2014).

An understanding of the relationship between the traits targeted for breeding and $Y$ is essential in order to adequately define the selection criteria (Okonkwo and Idahosa, 2013). Phenotypic correlations between traits can be directly measured (Falconer and Mackay, 1996), and although correlations have genetic and environmental causes, only genetic correlations are heritable and can be used in breeding programs (Cruz et al., 2012).

In Table 2, genotypic and phenotypic correlations between the traits are presented. Three aspects of the values are needed in order to interpret them: their magnitude, direction, and significance (Nogueira et al., 2012). Positive correlations indicate the tendency of a variable to 
increase when another increases, while negative correlations indicate the tendency of a variable to increase while another decreases (Cruz et al., 2012).

Table 2. Phenotypic and genotypic correlations between agronomic traits of 15 soybean genotypes naturally infected with Phakopsora pachyrhizi.

\begin{tabular}{|c|c|c|c|c|c|c|c|c|c|c|c|c|c|c|}
\hline Trait & & NNB & HIFP & NNM & HPM & NDB & NDM & NB & SEV & NP1G & NP2G & NP3G & TNP & $\mathrm{Y}$ \\
\hline \multirow[t]{2}{*}{ HPB } & $\mathrm{F}$ & 0.39 & 0.20 & 0.11 & $0.64^{* *}$ & 0.13 & -0.01 & $0.65^{\star *}$ & 0.49 & 0.40 & 0.28 & 0.41 & 0.37 & 0.36 \\
\hline & G & 0.41 & 0.36 & 0.10 & 0.64 & 0.15 & -0.02 & $1.10^{++}$ & 0.59 & 0.60 & 0.30 & 0.48 & 0.42 & 0.37 \\
\hline \multirow[t]{2}{*}{ NNB } & $\mathrm{F}$ & & $-0.52^{*}$ & 0.45 & 0.21 & $0.73^{\star *}$ & $0.52^{*}$ & 0.31 & -0.36 & $0.52^{*}$ & $0.75^{\star *}$ & $0.55^{*}$ & $0.73^{\star *}$ & 0.50 \\
\hline & G & & -0.90 & 0.48 & 0.23 & 0.80 & 0.56 & 0.54 & -0.48 & 0.91 & 0.90 & 0.66 & 0.87 & 0.57 \\
\hline \multirow[t]{2}{*}{ HIFP } & $\mathrm{F}$ & & & -0.31 & 0.18 & $-0.56^{*}$ & -0.48 & 0.07 & $0.71^{* *}$ & -0.12 & -0.44 & -0.29 & -0.41 & -0.36 \\
\hline & $\mathrm{G}$ & & & -0.48 & 0.28 & $-0.96^{+}$ & -0.79 & 0.08 & $1.00^{++}$ & -0.13 & -0.64 & -0.44 & -0.60 & -0.54 \\
\hline \multirow[t]{2}{*}{ NNM } & $\mathrm{F}$ & & & & $0.58^{*}$ & $0.67^{\star *}$ & $0.93^{\star *}$ & 0.44 & -0.48 & 0.10 & 0.32 & -0.11 & 0.15 & 0.23 \\
\hline & G & & & & 0.59 & 0.69 & 0.95 & 0.67 & -0.56 & 0.08 & 0.32 & -0.12 & 0.14 & 0.22 \\
\hline \multirow[t]{2}{*}{ HPM } & $\mathrm{F}$ & & & & & 0.07 & 0.36 & $0.68^{\text {** }}$ & 0.13 & 0.01 & 0.05 & -0.01 & 0.02 & 0.17 \\
\hline & G & & & & & 0.08 & 0.38 & $1.13^{++}$ & 0.13 & -0.01 & 0.06 & 0.00 & 0.04 & 0.19 \\
\hline \multirow[t]{2}{*}{ NDB } & $\mathrm{F}$ & & & & & & $0.78^{* *}$ & 0.32 & -0.45 & 0.32 & $0.65^{* *}$ & 0.35 & $0.57^{*}$ & 0.48 \\
\hline & $G$ & & & & & & 0.78 & 0.56 & -0.52 & $0.52+$ & 0.73 & 0.37 & 0.63 & 0.55 \\
\hline \multirow[t]{2}{*}{ NDM } & $\mathrm{F}$ & & & & & & & 0.32 & $-0.67^{\star *}$ & 0.16 & 0.40 & -0.04 & 0.24 & 0.28 \\
\hline & $\mathrm{G}$ & & & & & & & 0.54 & -0.77 & 0.25 & 0.45 & -0.03 & 0.26 & 0.31 \\
\hline \multirow[t]{2}{*}{ NB } & $\mathrm{F}$ & & & & & & & & 0.35 & 0.14 & 0.00 & 0.26 & 0.13 & 0.16 \\
\hline & G & & & & & & & & 0.70 & -0.12 & -0.15 & 0.46 & 0.12 & 0.17 \\
\hline \multirow[t]{2}{*}{ SEV } & $\mathrm{F}$ & & & & & & & & & 0.04 & -0.28 & 0.19 & -0.09 & -0.05 \\
\hline & $G$ & & & & & & & & & 0.23 & -0.29 & 0.27 & -0.05 & -0.07 \\
\hline \multirow[t]{2}{*}{ NP1G } & $\mathrm{F}$ & & & & & & & & & & $0.67^{* *}$ & $0.57^{*}$ & $0.71^{* *}$ & 0.51 \\
\hline & G & & & & & & & & & & 0.72 & 0.83 & 0.84 & 0.66 \\
\hline \multirow[t]{2}{*}{ NP2G } & $\mathrm{F}$ & & & & & & & & & & & $0.65^{\star *}$ & $0.94^{\star *}$ & $0.87^{\star *}$ \\
\hline & G & & & & & & & & & & & 0.69 & 0.94 & 0.93 \\
\hline \multirow[t]{2}{*}{ NP3G } & $\mathrm{F}$ & & & & & & & & & & & & $0.87^{* *}$ & $0.74^{\star *}$ \\
\hline & G & & & & & & & & & & & & 0.89 & 0.80 \\
\hline \multirow[t]{2}{*}{ TNP } & $\mathrm{F}$ & & & & & & & & & & & & & $0.89^{\text {** }}$ \\
\hline & G & & & & & & & & & & & & & 0.95 \\
\hline
\end{tabular}

${ }^{* *}$ Significant at the $1 \%$ probability level. ${ }^{*}$ Significant at the $5 \%$ probability level. ${ }^{+}$Significant at the $1 \%$ probability level. +Significant at the $5 \%$ probability level. HPB and HPM, height of the plant in bloom and at maturity, respectively; NNB and NNM, number of nodes on the main stalk and at maturity, respectively; NDB and NDM, number of days to bloom and number of days to maturity, respectively; HIFP, height of the insertion of the first pod; NP1G, number of pods with one grain; NP2G, number of pods with two grains; NP3G, number of pods with three grains; TNP, total number of pods; Y, grain yield; SEV, severity of Asian rust; NB, number of blisters $/ \mathrm{cm}^{-2} ; \mathrm{F}$, phenotypic correlation; G, genotypic correlation.

Regarding the magnitudes of the correlations, the estimates varied from -0.67 to 0.94 and from -0.90 to 1.13 for phenotypic and genotypic correlations, respectively (Table 2 ). Several correlations were not significant, i.e., they were zero, indicating that there was no linear relationship between those traits; however, as commented by Cruz et al. (2012), this does not necessarily mean that there was no association between the traits. In approximately $66 \%$ of the pairs of traits, the genotypic correlations were greater than the phenotypic correlations (Table 2), when at least one of the traits involved had a high heritability and genetic factors had a greater influence on the correlation than environmental factors. Similar results have been obtained previously (Almeida et al., 2010; Machikowa and Laosuwan, 2011; Nogueira et al., 2012).

HPB was significantly, positively correlated with NB, with a high genotypic correlation (Table 2). A significant, positive phenotypic correlation was found between HPB and HPM (Table 2), which is consistent with the results obtained by Nogueira (2011), who also found a significant genotypic correlation between the traits. Phenotypic correlations between NNB and NDB, NDM, NP1G, NP2G, NP3G, and TNP were significant and positive (Table 2), and genotypic correlations greater than 0.70 were obtained for NDB, NP1G, NP2G, and TNP (Table 2). Therefore, the 
selection of plants with long vegetative cycles indirectly contributed to the selection of plants with a large number of nodes, and, consequently, for the selection of plants with a large total number of pods, because the $H^{2}$ estimate for NDB was greater than $90 \%$ (Table 1). However, the correlation between NNB and HIFP was significant and negative (Table 2).

A significant, positive phenotypic correlation between HIFP and SEV was obtained. One possible explanation for this is the fact that high SEV values indicate the fall and abortion of flowers situated on the lower third of the plants. This correlation is not useful in a breeding program, because the HIFP is situated between 12 and $16 \mathrm{~cm}$ on the stem (Sediyama et al., 2005), and the $\mathrm{SEV}$ is the lowest possible.

Significant, positive correlations were not found between HIFP and Y agree with the results obtained by Ngalamu et al. (2012) over two planting seasons. However, the correlations between HIFP and HPM obtained in the present study disagree with those obtained by Oz et al. (2009) when evaluating correlations between $Y$ and its components, and the direct and indirect effects of these traits on yield in eight soybean cultivars in Turkey during two consecutive years, and with those of Nogueira et al. (2012) with 90 soybean cultivars in two planting seasons; however, they are similar to the results obtained by Almeida et al. (2010). We found significant, positive correlations between NNM and NDB, NDM, and HPM, and the genotypic correlations between these traits were greater than their phenotypic correlations (Table 2), indicating that the selection of late plants resulted in tall plants with a large number of nodes. Okonkwo and Idahosa (2013) also found a strong linear association between NNM and NDB.

Only the phenotypic correlation between HPM and NB was significant and positive, and was accompanied by a high-magnitude genotypic correlation (Table 2). This result disagrees with those obtained by El-Mohsen et al. (2013), who reported significant positive correlations between HPM and TNP with six soybean cultivars over two consecutive seasons when evaluating the effects of irrigation on different stages of seed development. NDB was significantly and positively phenotypically correlated with NDM, NP2G, and TNP, with genotypic correlations greater than 0.63 (Table 2). When evaluating morphological traits in 19 soybean genotypes in Iran under normal conditions and moisture stress, Salimi and Moradi (2012) also found a strong association between NDB and NDM, as did Nogueira et al. (2012). Almeida et al. (2010) reported a significant, positive correlation between NDB and Y. We obtained a significant, negative correlation between NDB and HIFP (Table 2).

The significant, negative phenotypic correlation obtained between NDM and SEV (Table 2 ) indicates that the higher the precocity of the plant the more severe the Asian rust on the leaf region tends to be. This fact is not relevant for breeding programs, and was probably observed in the current study because the rains had ceased, which resulted in extreme heat that is unfavorable for the development of fungi. This allowed late-cycle plants to develop and recuperate from the damage caused by Asian rust, while earlier plants were more severely damaged.

NP2G, NP3G, and TNP were positively and significantly phenotypically correlated with Y, and all of their genotypic correlations were stronger than their phenotypic correlations (Table 2). The strong linear association found between TNP and Y corroborate previous results (Arshad et al., 2006; Oz et al., 2009; El-Badaway and Mehasen, 2012; Nogueira et al., 2012; Valencia-Ramirez and Moreno, 2012; El-Mohsen et al., 2013; Okonkwo and Idahosa, 2013), suggesting that selection based on the number of pods per plant contributes to the selection of genotypes with high grain yields.

According to Cruz et al. (2012), a significant correlation is indicative of the viability of indirect selection, and agronomic traits are useful for constructing a selection index for the improvement of productivity (Naglamu et al., 2012). Considering that in the present study, the trait that had the greatest correlation with $\mathrm{Y}$ was TNP, other traits that also correlate with TNP, such as NDB, NNB, 
NP2G, and NP3G, should be important in breeding programs. Pípolo et al. (2005) obtained similar results when studying phenotypic correlations between NP2G and TNP in 34 lines of soybean.

Significant, positive environmental correlations indicate that the environment favors an increase in one trait and contributes to an increase in another. In this study, the strongest environmental correlation was between NP2G and TNP (Table 3). Environmental correlations between NDB, HPM, HIFP, TNP, and $Y$ were of low magnitude $(-0.20)$, and agree with the results obtained by Almeida et al. (2010) with 12 soybean genotypes.

\begin{tabular}{|c|c|c|c|c|c|c|c|c|c|c|c|c|c|}
\hline Trait & NNB & HIFP & NNM & HPM & NDB & NDM & NB & SEV & NP1G & NP2G & NP3G & TNP & Y \\
\hline HPB & $0.34^{++}$ & -0.03 & $0.28^{+}$ & $0.65^{++}$ & 0.21 & 0.14 & -0.02 & -0.01 & 0.08 & 0.08 & -0.13 & 0.01 & 0.30 \\
\hline NNB & & -0.11 & 0.34 & 0.11 & $0.29^{+}$ & $0.34^{+}$ & 0.05 & 0.09 & -0.09 & 0.03 & -0.08 & -0.02 & 0.18 \\
\hline HIFP & & & -0.17 & 0.06 & 0.14 & -0.11 & 0.06 & 0.01 & -0.12 & $-0.26^{+}$ & -0.13 & $-0.25^{+}$ & -0.20 \\
\hline NNM & & & & $0.35^{+}$ & 0.05 & 0.16 & 0.26 & 0.01 & 0.31 & 0.31 & -0.02 & 0.23 & $0.42^{+}$ \\
\hline HPM & & & & & -0.12 & 0.11 & 0.07 & 0.09 & 0.05 & -0.06 & -0.14 & -0.10 & 0.02 \\
\hline NDB & & & & & & $0.50^{+}$ & -0.17 & 0.06 & -0.23 & -0.30 & 0.04 & -0.21 & $-0.34^{++}$ \\
\hline NDM & & & & & & & -0.08 & 0.12 & -0.07 & $-0.24^{+}$ & -0.08 & $-0.21^{+}$ & -0.21 \\
\hline NB & & & & & & & & -0.06 & 0.32 & $0.29^{+}$ & -0.02 & 0.22 & $0.21^{+}$ \\
\hline SEV & & & & & & & & & $-0.27^{+}$ & -0.26 & -0.25 & -0.31 & 0.07 \\
\hline NP1G & & & & & & & & & & $0.77^{++}$ & 0.18 & $0.70^{++}$ & 0.35 \\
\hline NP2G & & & & & & & & & & & 0.37 & $0.92^{++}$ & $0.51^{+}$ \\
\hline NP3G & & & & & & & & & & & & $0.70^{++}$ & 0.29 \\
\hline TNP & & & & & & & & & & & & & $0.51^{+}$ \\
\hline
\end{tabular}

${ }^{++}$Significant at the $1 \%$ probability level. ${ }^{+}$Significant at the $5 \%$ probability level. HPB and HPM, height of the plant in bloom and at maturity, respectively; NNB and NNM, number of nodes on the main stalk and at maturity, respectively; NDB and NDM, number of days to bloom and number of days to maturity, respectively; HIFP, height of the insertion of the first pod; NP1G, number of pods with one grain; NP2G, number of pods with two grains; NP3G, number of pods with three grains; TNP, total number of pods; Y, grain yield; SEV, severity of Asian rust; NB, number of blisters/ $\mathrm{cm}^{-2}$.

\section{CONCLUSIONS}

The phenotypic and genotypic correlations found in this study indicate that the total number of pods is a useful trait for the indirect selection of soybean genotypes for a high grain yield. In plants naturally infected with $P$. pachyrhizi, the strongest environmental correlations were found between plant height at blooming and plant height at maturity, and between grain yield and its components.

\section{Conflicts of interest}

The authors declare no conflict of interest.

\section{ACKNOWLEDGMENTS}

The authors thank in the CNPq for the financial support of this study (postgraduate scholarship) and FAPEMIG (Foundation for Research Support of the State of Minas Gerais), which promotes encouragement, support and encourage scientific and technological research activities in Minas Gerais, enabling the study by providing financial assistance. 


\section{REFERENCES}

Almeida RD, Peluzio JM and Afferri FS (2010). Correlações fenotípicas, genotípicas e ambientais em soja cultivada sob condição várzea irrigada, sul do Tocantins. Biosc. J. 26: 95-99.

Almeida RD, Peluzio JM and Afferri FS (2011). Divergência genética entre cultivares de soja, sob condições de várzea irrigada, no sul do Estado Tocantins. Ciênc. Agro. 42: 108-115.

Alves JS, Espíndola SMC, Lucas FT, Teixeira GAC, et al. (2013). Severidade de doenças fúngicas em genótipos de soja semeados em Uberaba, MG. Rev. Agrarian 6: 236-244.

Arshad M, Ali N and Ghafoor AB (2006). Character correlation and path coefficient in soybean Glycine max (L.) Merrill. Pak. J. Bot. 38: 121-130.

Bárbaro IM, Centurion MAPDa, Mauro Di OOD, Unêda-Trevisoli SH, et al. (2007). Variabilidade e correlações entre produtividade de grãos e caracteres agronômicos de soja com aptidão para cultivo em áreas para reforma de canavial. Científica,136-14.

Barh A, Pushpendra RK and Joshi MB (2014). A new source of genetic divergence for soybean improvement. Afr. J. Agric. Res. 9: 119-124.

Cargnelutti Filho A and Gonçalves ECP (2001). Estimativa Do Número De repetições para a avaliação de caracteres de produtividade e de morfologia em genótipos de soja. Comun. Sci. 2: 25-33.

Carvalho CGP, Arias CAA, Toledo JFF, Almeida LA, et al. (2003). Proposta de classificação dos coeficientes de variação em relação à produtividade e altura da planta de soja. Pesqui. Agropecu. Bras. 38: 187-193.

CONAB. Companhia Nacional de Abastecimento. Acompanhamento da safra brasileira: grãos- oitavo levantamento (2015). Brasília: CONAB, 89p. Disponível: http://www.conab.gov.br. Acesso em: Maio, 2015.

Costa MM, Mauro Di AO, Trevisoli SHU, Arriel NHC, et al. (2004). Ganho genético por diferentes critérios de seleção em populações segregrantes de soja. Pesqui. Agropecu. Bras. 39: 1095-1102.

Cruz CD (2008). Programa Genes: diversidade genética. Viçosa, UFV.

Cruz CD, Regazzi AJ and Carneiro PCS (2012). Modelos Biométricos Aplicados Ao melhoramento genético. v. 01 , n.03 ed.Viçosa: UFV.

El-Badawy MEM and Mehasen SAS (2012). Correlation and path coefficient analysis for yield and yield components of soybean genotypes under different planting density. Asian J. Crop Sci. 4: 150-158.

El-Mohsen AAA, Mahmoud GO and Safina SA (2013). Agronomical evaluation of six soybean cultivars using correlation and regression analysis under different irrigation regime conditions. J. Plant Breed. Crop Sci. 5: 91-102.

Falconer DS and Mackay TFC (1996). Introduction to quantitative genetics, 4th edition. Longmans Green, Harlow, Essex, UK.

Fehr WR and Caviness CE (1977). Stages of soybean development. lowa State University, Ames.

Glasenapp JS, Sediyama T, Cruz CD, Matsuo E, et al. (2015). Diversidade de características agronômicas e moleculares em cultivares de soja com diferentes graus de resistência à Phakopsora pachyrhizi. Bioscience J. 31: 25-36.

Godoy CV, Koga LJ and Canteri MG (2006). Diagrammatic scale for assessment of soybean rust severity. Fitopatol. Bras. $30: 63-68$.

Gomez GM, Unêda-Trevisoli SHU, Pinheiro JB and Di Mauro AO (2014). Adaptive and agronomic performances of soybean genotypes derived from different genealogies through the use of several analytical strategies. Afr. J. Agric. Res. 9: $2146-2157$.

Lima LL, Nunes GHS and Bezerra Neto F (2004). Coeficientes de variação de algumas características do meloeiro: uma proposta de classificação. Hort. Bra. 22: 14-17.

Machikowa T and Laosuwan P (2011). Path coefficient analysis for yield of early maturing soybean. Songklanakarin J. Sci. Technol. 33: 365-368.

Malek MA, Rafii MY, Afroz MSS, Nath UK, et al. (2014). Morphological characterization and assessment of genetic variability, character association, and divergence in soybean mutants. Sci. World J. doi:10.1155/2014/968796.

Matsuo E, Sediyama T, Cruz CD, Oliveira RDL, et al. (2011). Genetic diversity in soybean genotypes with resistance to Genetic diversity in soybean genotypes with resistance to Heterodera glycines. Crop Breed. Appl. Biotechnol. 11: $304-312$.

Ngalamu T, Meseka S and Ashraf M (2012). Performance of soybean (Glycine max L. Merrill) genotypes under different planting dates in Sennar State of the Sudan. J. Appl. Biosci. 49: 3363-3370.

Nogueira APO (2011). Correlações, análises de trilha e diversidade fenotípica e molecular em soja. Doctoral thesis, Universidade Federal de Viçosa, Viçosa.

Nogueira APO, Sediyama T, Sousa LB, Hamawaki OT, et al. (2012). Análise de trilha e correlações entre caracteres em soja cultivada em duas épocas de semeadura. Bioscience J. 28: 877-888.

Okonkwo FA and Idahosa DO (2013). Heritability and correlation studies of yield characters in some soybean (Glycine max) 
varieties in Ekpoma. Am. J. Res. Commun.

Oz M, Karasu A, Goksoy T and Turan ZM (2009). Interrelationships of agronomical characteristics in soybean (Glycine max) grown in different environments. Int. J. Agr. Biol. 11: 85-88.

Pípolo VC, Gastaldi LF and Pipolo AE (2005). Correlações fenotípicas entre caracteres quantitativos em soja. Semina: Cienc. Agra. 26: 11-16.

Polizel AC, Alves CC, Hamawaki OT, Lima MA, et al. (2013). Desempenho agronômico de genótipos de soja de ciclosemiprecoce/médio em rondonópolis. Enciclop. Bio. 9: 986-993.

Priolli RHG, Mendes Junior CT, Sousa SMB, Sousa NEA, et al. (2004). Diversidade genética da soja entre períodos e entre programas de melhoramento no Brasil. Pesqui. Agropecu. Bras. 39: 967-975.

Ramalho MAP, Ferreira DF and Oliveira AC (2005). Experimentação Em Genética e melhoramento de plantas. 2 eds. Lavras: Editora UFLA.

Salimi S and Moradi S (2012). Effect the correlation, regression and path analysis in soybean genotypes (Glycin max I.) under moisture and normal condition. Int. J. Agron. Plant Prod. 3: 447-454.

Sediyama T, Teixeira RDC and Reis MS (2005). Melhoramento da Soja. In: Melhoramento de espécies cultivadas (Borém A, ed.). UFV, Viçosa.

Sediyama T, Silva F and Borém A (2015). Soja: do plantio à colheita. Viçosa. Editora UFV.

Valencia-Ramírez RA and Moreno GAL (2012). Phenotypic correlation and path analysis for yield in soybean (Glycine $\max (\mathrm{L}$.) Merrill) correlación fenotípica y análisis de sendero para el rendimiento de soya (Glycine max (L.) Merrill). Acta Agron. 61: 322-332.

Vasconcelos ES, Reis MS, Sedyiama T and Cruz DC (2012). Estimativas de parâmetros genéticos da qualidade fisiológica de sementes de genótipos de soja produzidas em diferentes regiões de Minas Gerais. Semina: Cienc. Agra. 33: 65-76.

Yorinori JT and Lazzarotto JJ (2004). Situação da ferrugem asiática da soja no Brasil e na América do Sul. Londrina: Embrapa soja. 